\title{
IAMJ
}

INTERNATIONAL

AYURVEDIC

MEDICAL JOURNAL

Review Article

ISSN: 23205091

Impact Factor: 5.344

\section{AHARA SAMPAT - THE EXCELLENCE OF DIET}

\section{Sapna Rajput ${ }^{1}$, M. R. Sajjan Shetty ${ }^{2}$, B. H. Katti ${ }^{3}$, Lohit Shaha ${ }^{4}$}

${ }^{1} \mathrm{PG}$ Scholar, ${ }^{2}$ Professor and HOD, ${ }^{3}$ Professor, Department of PG Studies in Samhita Siddhant, SVM Ayurvedic Medical college, Ilkal, Karnataka, India.

${ }^{4}$ Assistant Professor, Department of Anatomy, SNMC, Bagalkot, Karnataka, India

Corresponding Author: drsapnashaha@gmail.com

\section{https://doi.org/10.46607/iamj2208092020}

(Published online: September 2020)

Open Access

(C) International Ayurvedic Medical Journal, India 2020

Article Received:03/08/2020 - Peer Reviewed:15/09/2020 - Accepted for Publication:16/09/2020

Check for updates

\section{ABSTRACT}

The wellness of human beings is sustained by three factors Ahara, Nidra and Brahmacharya. Ahara plays an important role in maintaining health. As per Ayurveda Ahara is best preventive medicine and is solely responsible for health and illness. Regular dietary contents affect fundamentals of body having association with strength. Many factors are responsible to increase the Bala, in that Ahara Sampat is most important. Ahara Parinamkara Bhavas transform food from a complex form to a digestible and absorbable. Asta Aharavidhi Visheshayatana, there are 8 specific factors of methods of dietary rules. The rules to be followed during consumption of food which increases the quality of food for absorption has been explained in our classics as Vidhi Vidhan. Acharya Sushruta had explained under the 12 folds of consumption of food called as Dwadasha Asana Vidhi or Pravicharana. Hemadri has explained about seven types diet plan to be avoided. Complexion, cheerfulness, good voice, life, imagination, happiness, strength intellect etc. all these depends on food only. The application of Ahara and Ahara Vidhi Vidhan is effective to maintain of health and even in curative aspect of many Vyadhis.

Keywords: AharaSampat, AharaParinamkara Bhavas, Pravicharana, Ahara Vidhi Vidhan 


\section{INTRODUCTION}

Life is a divine gift and a disease-free sound health is a great blessing. Ayurveda said to be a primitive science which concentrates basically in maintaining healthy status of healthy and eradication of disease ${ }^{1}$. Ahara plays an important role in maintaining health. There are three basic pillars (Traya Upasthambas) of life, namely Ahara (food intake), Nidra (sleep) and Brahmacharya (celibacy) ${ }^{2}$. The wellness of human beings is sustained by these three factors. Ahara is $1 / 3^{\text {rd }}$ part of Trya Upastambha that is supporting pillars of body. It has given prime importance about Ahara to maintain health, it is considered as a best sustainer of life. Ahara plays an important role in maintaining of equilibrium of Dhatus, promote the health and prevents the body from diseases.

Generally, all the edible substance is called as Ahara, but after all the substance which can be swallowed and also provides nutrition to the body is called as Ahara. According to Ayurveda Ahara is best preventive medicine and is solely responsible for health and illness, sorrow and happiness. Although specific drugs are required for management of specific diseases, but Ahara is best of all medicines also called as Mahabhaisjayam by Acharya Kashyap ${ }^{3}$.

There are three types of Bala according to Acharya Charaka they are viz Sahaj, Kalaj and Yuktikrita ${ }^{4}$. Bala (strength) is a broad concept in terms of Ayurveda. Bala is characteristic feature of healthy, physical and mental state of body. Bala can be obtained by dietary contents and Bala promoting drugs from $1^{\text {st }}$ month of gestation to get supreme mental and physical strength.

According to Acharya Sushrut, Bala is Rasaj and Satymaj Bhava. Rasaj Bhava develops from Prakrut Ahara Rasa circulating through pregnant mother to her fetus and Satmyaj Bhava depends on Satmyaj Ahara consumed by mother also these both Bhava factors can be improved throughout the life of individual ${ }^{5}$. Dietary contents affect fundamentals of body having association with strength. There are many factors to increase the Bala, that is Bala Vridhhikar Bhavas, in that Ahara Sampat (excellence) is one of those factors.
Regular Factors enhancing Bala are considered under Bala Vriddhikar Bhavas they can be as proper diet, wholesome practices, pure mental status, daily practices, and joyful living etc 6 . Proper diet i.e. Ahara Sampat, excellence in diet is having all kinds of taste to enhance Bala. "Sarva Rasabhyaso Balakaranam" "Annam Vruttikaranam" in the chapter of Yajjpurushiya Adhaya Acharya Charaka says that food is one among prominent and best factor in life ${ }^{7}$. Regular intake of all the Rasas helps in enhancing the Bala.

Ahara Sampat i.e. excellence of diet indicates that food with all required nutrition in an adequate quantity helps in preservation and promotion of health gives strength, vitality, endurance and improves immunity.

\section{Ahara Parinamkara Bhavas}

Factors that transform food from a complex form to a digestible and absorbable for, they are Ushma (Hotness), Vayu (air), Kleda (unctuous), Sneha (oiliness), Kala(time) and Samyoga (combination) ${ }^{8}$. The heat digests, Vayu absorbs, moister produces looseness, unctuousness generates softness, time brings sufficiency and balanced use brings about equilibrium of Dhatus which are the products of digestion'.

\section{Asta Aharavidhi Visheshayatana}

There are 8 specific factors of methods of dietary rules. It determines the utility of food, depending upon methods of preparation, taste, smell, presentation etc ${ }^{10}$.

Prakriti- (Nature of food) Based on its Guna (qualities) like Laghu, Guru etc. affects the body e.g. green gram is light and black gram is heavy to digest. Karan-(Method of processing) Processing of inherent attribute of a substance results in transformation of qualities. It is also called as Sanskara. E.g. churning, cooking, dilution, emulsification etc. Samyoga (Combination) Combination of two or more substances results in manifestation of new qualities e.g. Honey and ghee in equal quantity is antagonistic ${ }^{11}$. Milk with ghee used regularly is the best Rasayan ${ }^{12}$. Rashi (Quantity) The proper amount of food is important for proper digestion which kindles the Agni. A person should have his diet in proper amount according to his digestive power. The insufficient and excess amount 
of food, both are harmful. Desha - (Habitat) it denotes place relating to growth as well as distribution of the substance and also the suitability in respect to place and person. e.g. Use of hot substances in marshy land and cold substances in deserts. Kala - (Time) The time eternal one and conditional both are important when related to disorders. The time used in relation to disease i.e. Avasthik Kala and in relation to seasonal wholesomeness i.e. Nithyaga Kala, in form of day and night. In Swastha Avastha Ahara should be taken according Dinacharya and Rutucharya. In Rugnavastha, Ahara should be consumed according to the stage of the disease ${ }^{13}$. Upayoktasamstha- It denotes the dietary rules. Upayokta (user) - The individual who is using food. Creating the wholesomeness of food for that individual is called as Satmya which differ person to person.

\section{Bhojya Sadgunynam (Rules related to Rasadi Samyoga)}

It is summed up in Vimanastana $1^{\text {st }}$ chapter, Rasa, drugs, Doshas and disorders in effects, substances not to be used excessively, three-fold suitability, eight factors of diet and merits of food all have shown its importance $^{14}$.

There are some rules to be followed during consumption of food which increases the quality of food for absorption which are stated in our Brihatrayees under the heading of Vidhi Vidhan. Acharya Sushruta had explained under the 12 folds of consumption of food called as Dwadasha Asana Vidhi or Pravicharana ${ }^{15}$.

Sheetahara- To have cold food, it is in case of thirst, alcoholic person, burning sensation, diseases like Raktapitta and in emaciated individuals. Ushnahara- To have warm and hot food this is useful in persons with Kaphaj diseases and also after Shondhan therapies. SnigdhaAhara- To have unctuous food, which is indicated in Ruksha individual, persons with Vata Prakriti and Vata disorders. Ruksha Ahara- To have - unctuous or Ruksha food which is useful in obese persons, diabetics and individuals with more of Kapha. Drava Ahara- To have liquid food in case of dehydrated and weak individuals. ShuskaAhara- To have dry or Shus$k a$ food, which is indicated in the patient of Praklinna Kaya, Vranita and Prameha Pidita persons. Ek Kalika
Ahara- The food to be taken only once a day as it is helpful in impaired Agni (digestion). Dvi Kalika Ahara- Food taken twice a day with little proper Agni like Samagni persons. AushadhaYuktaAhara- As it is suggested food mixed with required herbs and drugs should be used for the person who cannot take medicine directly. Matraheen Ahara- Food intake should be reduced due to impaired Agni and diseases related to Mandagni. Prashamaka Ahara- To pacify the Doshas i.e. Dosha Prashamaka food is advised according to daily, seasonal regimen and variations. Vrittiprayojak Ahara- To promote health this food is advised, Shareera Nirvahana and Sarva Rasa Yukta.

Ahara Samyak Yogasya Tyaga Saptadha (Diet to be avoided)

Hemadri in his commentary Ayurveda Rasayana has explained about seven types diet plan to be avoided ${ }^{16}$. Sankirashan (impure diet), that which is contaminated by hair, grass etc. should be rejected. Viruddhashan (incompatible diet). Amatrashan (unjustified diet), proper quantity of food is essential but inappropriate food intake leads to different diseases like Alasak, Visuchika by Amatrashan. Ajeernashan (in condition of indigestion), different kinds of indigestion are manifested by intake of large amount of food when Amadosha is present. Samshaman (mixing wholesome and unwholesome together), it is applied when intake of suitable and unsuitable food is taken together ${ }^{17}$. Adhyashan consuming large quantity before previous meal is digested. Vishamasan, taking food in improper time.

\section{DISCUSSION}

The human body requires food to provide energy for all life processes, growth, repair and maintenance. Eating a well-balanced diet on a regular basis and staying at ideal weight are critical factors in maintaining emotional and physical wellbeing.

"Yad Annam Dehadhatvo" Food nourishes all the Dhatus, Ojas, strength gives complexion etc. it all depends on Agni in the body because Ras can't be produced from undigested food so Ahara is important ${ }^{18}$. Food energies the mind, our strength, health and life depend on Agni and Agni is constantly replen- 
ished by the food. Strength, energy mental clarity, radiance, immunity and sharpness of the senses all depends on the food we eat.

Food taken in the various form eaten, drunk, licked which is wholesome for the person being consumed properly by the respective Agni (digestive factors) etc. provides Bala (energy) to the body tissues ${ }^{19}$. Food provides the building blocks that create new Dhatus in the body, Dhatus are reservoirs of energy in various food. Eating balanced food is of utmost importance for energy. Diet planning according to Ayurveda is based on Prakriti of Ahara as well as person, Kaarana, Sanyoga, Satmya, Agni, Matra, Desha Kala and Ahara Vidhi Vidhan in healthy person.

Modern dietics address food on the basis of calorific values amount of carbohydrates, proteins, fats, vitamins and minerals. Not following the proper dietics rules is one of the most privileging factors for the manifestation of lifestyle disorders. Diet intake with dietics rules has a vital role to prevent and manage the lifestyle disorders. The rules tell about "what, when, why, which and how" to eat the diet. Now people are very much conscious about quality, nutritional value, wholesome unwholesome diet, so it indicates only "what to eat" but not "how to eat".

In present era because of modern lifestyle most people are following the wrong dietic rules than the proper dietic rules which are the important causative factor for manifesting lifestyle disorders. In this fast-forward life when people are feeling hungry due to work pressure, they are suppressing their hunger, leading to Adhyasana, Samshana.

"Prana Pranabhruttanam" Food is essential for life and is Prana. Food is the vital breadth of living beings and that is why people rush to have food. Complexion, cheerfulness, good voice, life, imagination, happiness, strength intellect etc. all these depends on food only ${ }^{20}$. Food is often called as Poornabhrahma, it not only nourishes the body but the mind and soul as well. The diet is critical in disease also. Unhealthy or in appropriate food choices can easily become the cause for several diseases. Making healthy food choices or eating right foods can reverse this and serve as a treatment for disease. Eating right diet is critical to main- tain health or prevent disease and to combat illness, should it arise as a result of improper food choices. One man's food is other man's poison.

The Ayurvedic concept of Ahara Vidhi Vidhan allows us to expand the conversation into answering the most important questions "why did the body begin to improperly digest or not tolerate this food? And how can we both eliminate the offending agent and concurrently increase Agni or digestive power? To bestow the total benefit of Ahara Vidhi Vidhan is been told.

\section{CONCLUSION}

Ayurveda classics are ocean of valuable thoughts. There are many precious concepts in field of Ahara in our classics. These concepts of Ahara should be followed to lead a healthy life. Not only the Ahara even diet intake rules are also important to lead a perfect life. The application of Ahara and Ahara Vidhi Vidhan is effective to maintain of health and even in curative aspect of many Vyadhis (diseases).

The rules and different methods of diet intake, preparation etc. have important role in healthy person to live. The rules and methods under Asta AharaVidhi Visheshayatani, Ahara Vidhi Vidhan by Acharaya Charak and Dwadhasa Asana Vidhi/Pravicharana by Acharya Sushruta has been explained for excellence of diet (AharaSampat).

\section{REFERENCES}

1. Sushruta, Sushruta Samhita Edited with Ayurved Tattva- Sandipika Hindi Commentary by Kaviraj Ambikadutta Shastri, Reprint 2018, Chaukhambha Sanskrit Sansthan, Varanasi, Sutrastana volume 1, $1^{\text {st }}$ chapter $36^{\text {th }}$ shloka, page no 10 .

2. Agnivesa, Charaka Samhita by Prof. Priyavrat Sharma, Edition 2014, Chaukhambha Orientalia, Varanasi, Sutrastana volume $1,11^{\text {th }}$ chapter $35^{\text {th }}$ shloka, page no 75 .

3. Vruddha Jeevaka, Kashyap Samhita, Edition 2010, Chaukhambha Sanskrit Sansthan, Varanasi, Kilastana, $4^{\text {th }}$ chapter $6^{\text {th }}$ shloka, page no 249 .

4. Agnivesa, Charaka Samhita by Prof. Priyavrat Sharma, Edition 2014, Chaukhambha Orientalia, Varanasi, Sutrastana volume $1,11^{\text {th }}$ chapter $36^{\text {th }}$ shloka, page no 75 .

5. Sushruta, Sushruta Samhita Edited with Ayurved Tattva- Sandipika Hindi Commentary by Kaviraj Ambikadutta Shastri, Reprint 2018, Chaukhambha Sanskrit 
Sansthan, Varanasi, Sutrastana volume $1,15^{\text {th }}$ chapter $24^{\text {th }}$ shloka, page no 79 .

6. Agnivesa, Charaka Samhita by Prof. Priyavrat Sharma, Edition 2014, Chaukhambha Orientalia, Varanasi, Sharirstana volume $1,6^{\text {th }}$ chapter $13^{\text {th }}$ shloka, page no 449.

7. Agnivesa, Charaka Samhita by Prof. Priyavrat Sharma, Edition 2014, Chaukhambha Orientalia, Varanasi,Sutrastana volume $1,25^{\text {th }}$ chapter $40^{\text {th }}$ shloka, page no 169 .

8. Agnivesa, Charaka Samhita by Prof. Priyavrat Sharma, Edition 2014, Chaukhambha Orientalia, Varanasi, Sharirstana volume $1,6^{\text {th }}$ chapter $13^{\text {th }}$ shloka, page no 449.

9. Agnivesa, Charaka Samhita by Prof. Priyavrat Sharma, Edition 2014, Chaukhambha Orientalia, Varanasi, Sharirstana volume $1,6^{\text {th }}$ chapter $15^{\text {th }}$ shloka, page no 449.

10. Agnivesa, Charaka Samhita by Prof. Priyavrat Sharma, Edition 2014, Chaukhambha Orientalia, Varanasi, Vimanstana volume $1,1^{\text {st }}$ chapter $21^{\text {st }}$ shloka, page no 305.

11. Agnivesa, Charaka Samhita by Prof. Priyavrat Sharma, Edition 2014, Chaukhambha Orientalia, Varanasi, Sutrastana volume $1,26^{\text {th }}$ chapter $84^{\text {th }}$ shloka, page no 189 .

12. Agnivesa, Charaka Samhita by Prof. Priyavrat Sharma, Edition 2014, Chaukhambha Orientalia, Varanasi, Sutrastana volume $1,25^{\text {th }}$ chapter $40^{\text {th }}$ shloka, page no 168 .

13. Agnivesa, Charaka Samhita by Prof. Priyavrat Sharma, Edition 2014, Chaukhambha Orientalia, Varanasi, Vimanstana volume $1,1^{\text {st }}$ chapter $21^{\text {st }}-6$ shloka, page no 306.

14. Agnivesa, Charaka Samhita by Prof. Priyavrat Sharma, Edition 2014, Chaukhambha Orientalia, Varanasi, Vimanstana volume $1,1^{\text {st }}$ chapter $28^{\text {th }}$ shloka, page no 309.

15. Sushruta, Sushruta Samhita Edited with Ayurved Tattva- Sandipika Hindi Commentary by Kaviraj Ambikadutta Shastri, Reprint 2018, Chaukhambha Sanskrit Sansthan, Varanasi, Uttartantra volume $2,64^{\text {th }}$ chapter $56^{\text {th }}$ shloka, page no 618 .

16. Vagbhata, Astanga Hrdaya with Sarvangasundar of Arundutta and Ayurveda Rasayana of Hemadri Hindi commentaries annotated by Dr Anna MoreshwarKunte and Krshna Ramchandra Navre edited by Pt. Hari Sadashiv Shastri Paradakara,1997, Chaukhambha Surbharati Prakashan, Varanasi, Sutrastana, $8^{\text {th }}$ chapter commentary, page no 147.
17. Vagbhata, Astanga Hrdaya by Prof. K. R. Srikantha Murthy, $9^{\text {th }}$ Edition, Chaukhambha Krishnadas Academy, Varanasi, Sutrastana volume $1,8^{\text {th }}$ chapter $33^{\text {rd }}$ shloka, page no 130 .

18. Agnivesa, Charaka Samhita by Prof. Priyavrat Sharma, Edition 2014, Chaukhambha Orientalia, Varanasi, Chikitsastana volume $2,15^{\text {th }}$ chapter $5^{\text {th }}$ shloka, page no 250 .

19. Agnivesa, Charaka Samhita by Prof. Priyavrat Sharma, Edition 2014, Chaukhambha Orientalia, Varanasi, Sutrastana volume $1,28^{\text {th }}$ chapter $3^{\text {rd }}$ shloka, page no226.

20. Agnivesa, Charaka Samhita by Prof. Priyavrat Sharma, Edition 2014, Chaukhambha Orientalia, Varanasi, Sutrastana volume $1,27^{\text {th }}$ chapter $349^{\text {th }}$ shloka, page no225.

\section{Source of Support: Nil Conflict of Interest: None Declared}

How to cite this URL: Sapna Rajput et al: Ahara Sampat The Excellence Of Diet. International Ayurvedic Medical Journal \{online\} 2020 \{cited September, 2020\} Available from:

http:/www.iamj.in/posts/images/upload/4442 4446.pdf 